\title{
X-linked centronuclear myopathy
}

INSERM

\section{Source}

INSERM. (1999). Orphanet: an online rare disease and orphan drug data base. $\underline{X \text {-linked }}$ centronuclear myopathy. ORPHA:596

X-linked myotubular myopathy (XLMTM) is an inherited neuromuscular disorder defined by numerous centrally placed nuclei on muscle biopsy and clinical features of a congenital myopathy. 